\title{
HIV Tat Protein Increases Bcl-2 Expression in Monocytes Which Inhibits Monocyte Apoptosis Induced by Tumor Necrosis Factor-Alpha-Related Apoptosis-Induced Ligand
}

\author{
Lin Zheng $^{\text {a }}$ Yida Yang $^{\text {a }} \quad$ Lu Guocai $^{a} \quad$ C. David Pauza ${ }^{b}$ Maria S. Salvato ${ }^{b}$ \\ a Department of Infectious Diseases, The First Affiliated Hospital, Medical School, Key Laboratory of \\ Infectious Diseases of Chinese Ministry of Public Health, Zhejiang University, Hangzhou, Zhejiang, PR China; \\ ${ }^{b}$ Institute of Human Virology, University of Maryland Biotechnology Center, Baltimore, Md., USA
}

\section{Key Words}

HIV Tat $\cdot$ Bcl-2 $\cdot$ Monocytes $\cdot$ Apoptosis $\cdot$ TRAIL

\begin{abstract}
Objective: To investigate the effect of HIV Tat protein on $\mathrm{BCl}$ 2 expression in human monocytes, and observe apoptosis of Tat-stimulated monocytes induced by TNF- $\alpha$-related apoptosis-induced ligand (TRAIL). Methods: Western blot was used to detect $\mathrm{Bcl}-2$ expression in monocytes stimulated by HIV Tat protein, and Annexin $\mathrm{V}$ and 7-AAD staining were used to detect apoptosis of monocytes induced by TRAIL. Results: HIV Tat protein increased Bcl-2 expression in human monocytes in a dose-dependent manner. Annexin $\mathrm{V}$ staining showed that $51.54 \%$ of monocytes underwent apoptosis after being treated with $100 \mathrm{ng} / \mathrm{ml}$ recombinant TRAIL. When monocytes were prestimulated with HIV Tat, only $15.46 \%$ of monocytes underwent apoptosis. This effect can be inhibited by polyclonal anti-Tat serum. 7-AAD staining showed similar results. Conclusion: HIV Tat protein increases $\mathrm{BCl}$-2 expression in monocytes which inhibited apoptosis induced by TRAIL. HIV Tat protein may play an important role in the mechanisms of HIV-persistent infection in monocytes.

Copyright $\odot 2007$ S. Karger AG, Basel
\end{abstract}

\section{Introduction}

The human immunodeficiency virus-1 (HIV-1) Tat protein is essential for HIV-1 transcription and replication and also modulates the expression of genes responsible for cell survival and proliferation $[1,2]$. Tat is also a secreted protein that can be detected in the sera from HIV-infected patients [3]. Cells treated with Tat showed increased expression of chemokine receptors, over-production of interferon- $\alpha$ (IFN- $\alpha$ ) and enhanced expression of Fas ligand and TNF- $\alpha$-related apoptosis-induced ligand (TRAIL). Tat can also be taken up by monocytes, thus inducing biological effects through an auto-/paracrine mechanism [4-6].

HIV induces cell death by many mechanisms, including both direct and bystander-mediated apoptosis. The monocyte/macrophage lineage serves as an important reservoir for HIV in the body and is not only refractory to HIV-induced cell death but also can cause the death of bystander CD4+ T lymphocytes [7, 8]. The mechanism by which HIV-infected monocytes induce bystander CD4+ T lymphocyte death include Fas ligand and TRAIL production $[6,9]$.

The ability of monocyte/macrophages to avoid virusinduced cell death subsequent to HIV infection qualifies them as an important cellular reservoir for active viral

Dr. Yida Yang

Department of Infectious Diseases, The First Affiliated Hospital

Medical School, Zhejiang University

Hangzhou, Zhejiang 310003 (PR China)

Tel./Fax +86 5718602 6391, E-Mail yidayang@hotmail.com 
replication. But the mechanism is not fully understood. Here we focus on the regulation of the anti-apoptotic Bcl2 gene in HIV Tat-treated monocytes and its relation to TRAIL-induced apoptosis.

\section{Materials and Methods}

\section{Reagents}

HIV Tat protein, Tat-86, with a C-terminal truncation of 15 amino acids, and anti-Tat (ARRRP\#709) are from the US NIH AIDS Research and Reference Program, ARRRP. Mouse anti-human immunoglobulin G1(IgG1; Sigma, St. Louis, Mo., USA), recombinant TRAIL (rTRAIL, eBiosciences, San Diego, Calif., USA), a neutralizing monoclonal anti-TRAIL (N2B2; eBiosciences), and anti-Bcl-2 (Santa Cruz Biotechnology; San Diego, Calif., USA). 7-amino-actinomycin D (7-AAD; Sigma), propidium iodide (Sigma), annexin V-fluorescein isothiocyanate (FITC) (Pharmingen, San Diego, Calif., USA) were used for flow cytometry.

\section{Cell and Cell Culture}

Human monocytes were isolated from PBMC of healthy donors by adherence to plastic (i.e. they were incubated for $2 \mathrm{~h}$ in T125 flasks in RPMI 1640 medium containing 10\% heat-inactivated $\mathrm{AB}$ serum). Fluorescence-activated cell sorter analysis demonstrated that more than $98 \%$ of the cells were CD14+, indicating monocytes of high purity.

\section{Immunoblotting Assay}

Monocytes were stimulated with HIV Tat $(0-500 \mathrm{ng} / \mathrm{ml})$ for $20 \mathrm{~h}$. The stimulation took place in 96 -well plates at 37 with $3 \times$ $10^{5}$ cells/well in a volume of $100 \mu$ l of RPMI 1640 medium plus $10 \%$ FCS. At the end of these incubations, cells were lysed at $4^{\circ}$ in a buffer containing 1\% NP-40, $50 \mathrm{~mm}$ Tris- $\mathrm{HCl}(\mathrm{pH} 7.5), 150 \mathrm{~mm}$ $\mathrm{NaCl}, 10 \mathrm{~mm}$ EDTA, $1 \mathrm{~mm}$ phenylmethylsulfonyl fluoride, $1 \%$ aprotinin, and $1 \mathrm{~mm}$ pepstatin $\mathrm{A}$. The lysate was sonicated for $30 \mathrm{~s}$ at maximum setting (Ultrasonic Cleaner; Branson, Danbury, Conn., USA) and was centrifuged at $1,000 \mathrm{~g}$ for $10 \mathrm{~min}$ at $4^{\circ}$ to pellet debris. Cell lysates were analyzed by sodium dodecyl sulfate- $10 \%$ polyacrylamide gel eletrophoresis (SDS-10\% PAGE) using $20 \mu$ l of undiluted medium per well or $6 \times 10^{4}$ cell equivalents of lysate. The separated proteins were transferred to nitrocellulose membranes. Membranes were sequentially incubated with anti-Bcl-2 and then with a corresponding secondary antibody conjugated with horseradish peroxidase and were detected with an electrochemiluminescent system (ECL; Amersham Pharmacia Biotech, Piscataway, N.J., USA).

\section{Reverse Transcription-PCR}

Total RNA was extracted from $2 \times 10^{6}$ cells by using Trizol regent (Invitrogen, Carlsbad, Calif., USA), followed by treatment with RNase-free DNase (Promega, Madison, Wisc., USA). cDNA was synthesized from $1 \mu \mathrm{g}$ of RNA by using AMV reverse transcriptase (Promega) as described previously [6]. PCRs were performed using the following primers: for Bcl-2, 5'-GACGCACATGCGCAACAGTATC-3' (forward), and 5'-GTTCGTGACGAATGATTGCCCG-3' (reverse), and for actin, 5'-GGGTCAGAAGGATTCCTATG-3'(forward), and 5'-GGTCTCAAACATGATCT-

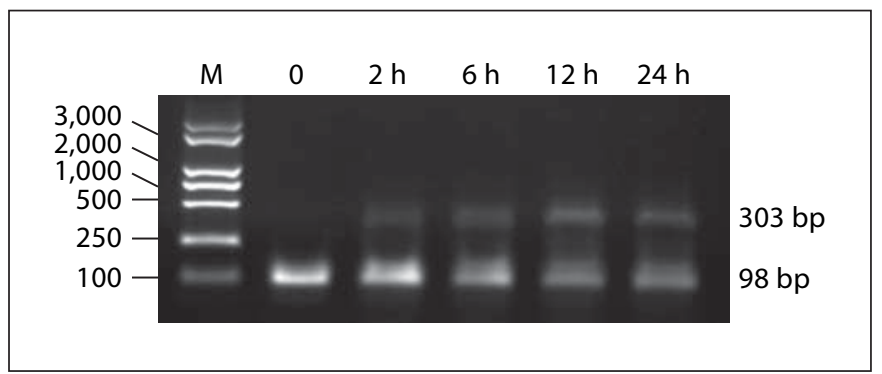

Fig. 1. HIV Tat induces the transcription of TRAIL mRNA in monocytes. Total RNA from human monocytes was isolated and subjected to reverse transcription-PCR. Bcl-2 mRNA was amplified over 35 cycles and $\beta$-actin mRNA was amplified over $25 \mathrm{cy}$ cles of PCR. Transcription of Bcl-2 in human monocytes is shown after $0,2,6,12$ or $24 \mathrm{~h}$ of incubation in the presence of HIV Tat (100 ng/ml).

GGG-3'. The Bcl-2 PCR cycle conditions were $94^{\circ}$ for $1 \mathrm{~min}, 55^{\circ}$ for $1 \mathrm{~min}$, and $72^{\circ}$ for $1 \mathrm{~min}$ for a total of 35 cycles. The $\beta$-actin cycle conditions were $94^{\circ}$ for $45 \mathrm{~s}, 72^{\circ}$ for $1 \mathrm{~min}, 55^{\circ}$ for $45 \mathrm{~s}$ for a total of 25 cycles. Samples were resolved on a $1 \%$ agarose gel and visualized with ethidium bromide.

\section{Cytometry Assay}

Cell viability was routinely checked by trypan blue exclusion. For flow cytometry for detection of apoptosis, aliquots of $10^{5}$ cells were washed and incubated in the dark at 4 for 20 min in PBS containing either $5 \mu \mathrm{l}$ of annexin V-FITC (to detect early apoptosis) or $20 \mu \mathrm{g}$ of $7-\mathrm{AAD} / \mathrm{ml}$ (to detect late apoptosis) [10]. Cells were processed according to the manufacturer's protocol and fixed in PBS-bovine serum albumin- $\mathrm{NaN}_{3}$ buffer containing $1 \%$ paraformaldehyde. Samples were analyzed $20 \mathrm{~min}$ later by FACScan flow cytometry.

\section{Results}

\section{HIV Tat Protein Increases Bcl-2 mRNA Transcription in Human Monocytes}

The transcription of Bcl-2 mRNA was rapidly induced within $2 \mathrm{~h}$ after the addition of Tat, and expression was sustained throughout overnight culture in freshly isolated human monocytes (fig. 1).

\section{HIV Tat Protein Increases Bcl-2 Expression in \\ Monocytes}

Fresh human monocytes were stimulated with HIV Tat $(0-500 \mathrm{ng} / \mathrm{ml})$ at $37^{\circ}$, and lysates were collected after $24 \mathrm{~h}$. Immunoblotting results showed that HIV Tat increases the expression of $\mathrm{Bcl}-2$ in a dose-dependent manner. Boiled HIV Tat was incapable of inducing Bcl-2 in monocytes (fig. 2). 


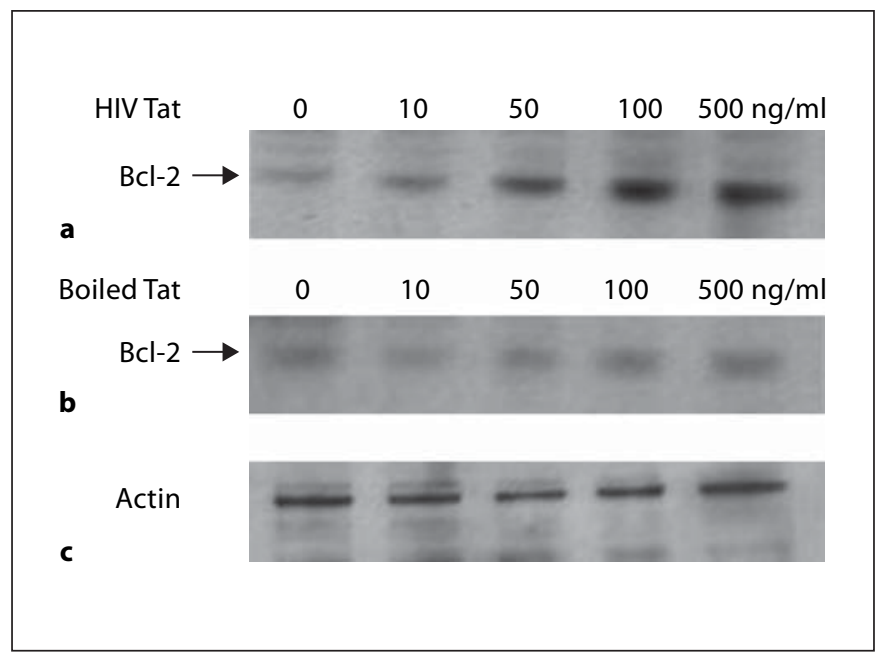

Fig. 2. HIV Tat increases Bcl-2 expression in human monocytes, boiled Tat does not. Bcl-2 expression increases with increasing dose of Tat protein. Monocytes were incubated with or without HIV Tat (a) or boiled Tat (b) $(10-500 \mathrm{ng} / \mathrm{ml})$ at $37^{\circ}$ for $24 \mathrm{~h}$, and cell lysate was separated by SDS-10\% PAGE. Cell proteins were transferred to nitrocellulose membranes and immunoblotted with anti-Bcl-2. Lanes (from left): 1, no Tat protein, 2-5 monocytes exposed to $10,50,100$ and $500 \mathrm{ng}$ of Tat $/ \mathrm{ml}$, respectively. c Actin was an internal control.

\section{HIV Tat Protein Protects Human Monocytes from} Apoptosis Induced by TRAIL

Initially we used annexin $\mathrm{V}$ staining to check the apoptosis of recombinant TRAIL on human monocytes. The results showed that $51 \%$ of monocytes underwent apoptosis after being stimulated by $100 \mathrm{ng} / \mathrm{ml}$ of rTRAIL. At the same time only $15 \%$ of monocytes underwent apoptosis after culture with $100 \mathrm{ng} / \mathrm{ml}$ of HIV Tat for $24 \mathrm{~h}$. This protection decreased when polyclonal anti-Tat was preincubated with HIV Tat (fig. 3). Results after 7AAD staining were similar (fig. 4).

\section{Discussion}

Extracellular HIV Tat has multiple effects on human monocytes, including upregulation of cytokine expression, upregulation of HIV coreceptor expression, promotion of chemotaxis and promotion of microvascular invasion [1]. We demonstrated that HIV Tat increased Bcl-2 expression in monocytes in a dose-dependent manner. After exposure to recombinant TRAIL, $51.54 \%$ of monocytes underwent apoptosis; however, when monocytes
Fig. 3. HIV Tat protein protects monocytes from apoptosis induced by TRAIL (annexin V staining). Monocytes incubated without rTRAIL (a) or $100 \mathrm{ng} / \mathrm{ml}$ of rTRAIL (b) and HIV Tat prestimulated monocytes incubated with $100 \mathrm{ng} / \mathrm{ml}$ of rTRAIL (c) or (anti-Tat and HIV Tat) prestimulated monocytes incubated with 100 $\mathrm{ng} / \mathrm{ml}$ of rTRAIL (d) for $20 \mathrm{~h}$ and then stained with annexin $\mathrm{V}$ as described in 'Materials and Methods'. Data from three independent experiments were similar.

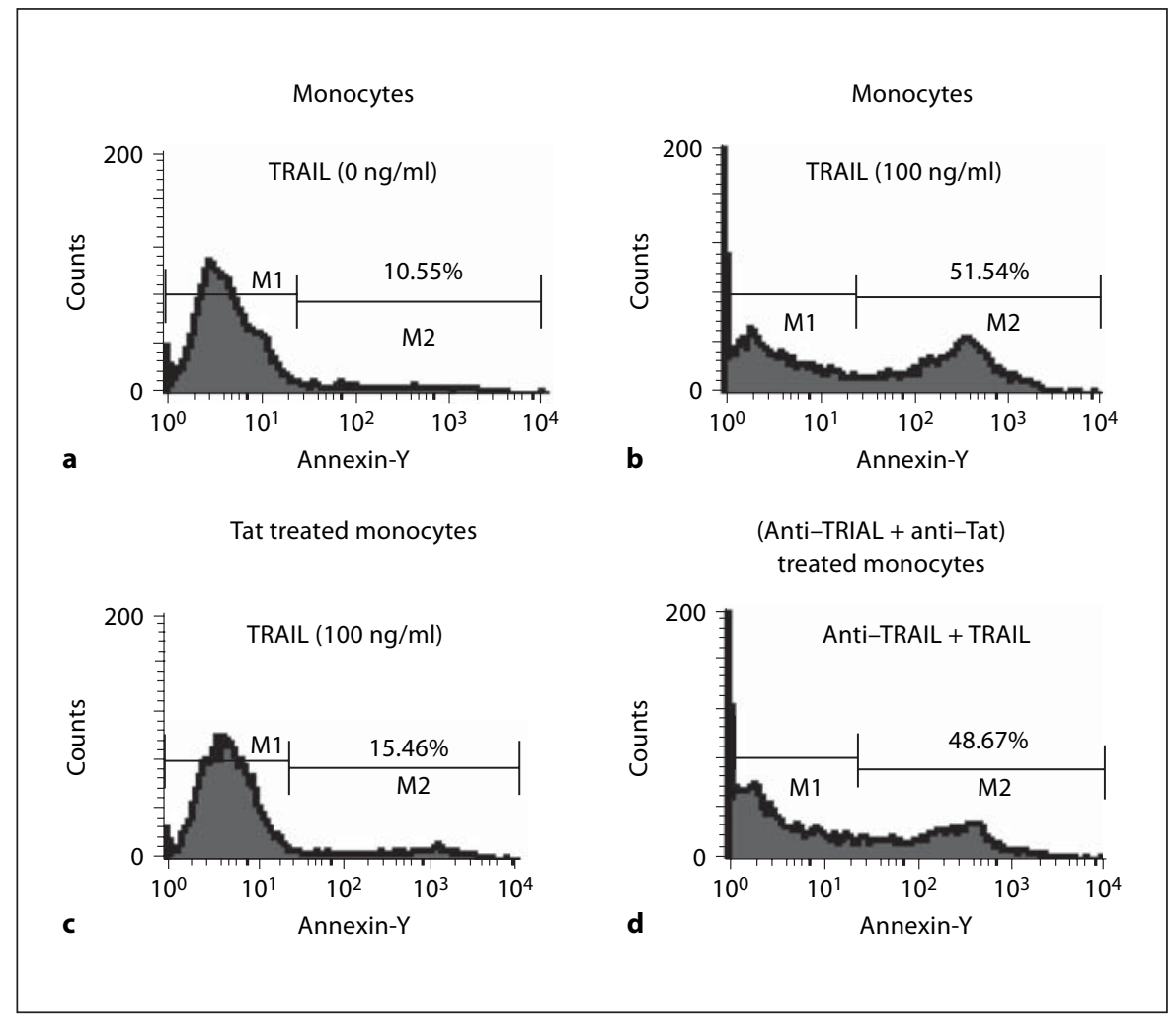


were preincubated with HIV Tat for $24 \mathrm{~h}$, only $15.46 \%$ of monocytes underwent apoptosis upon stimulation with rTRAIL.

Although Tat was shown to increase cell death in cultured PBMC, we and others demonstrated that infected cells were resistant to the pro-apoptotic effects of Tat $[6$, 11]. The fact that TRAIL is more toxic to uninfected cells, including CD4+ T lymphocytes and monocytes, provides a molecular basis for the observation of bystander cell death $[6,11]$. Although it has been shown that B lymphocytes acquired resistance to TRAIL by downregulating receptors TRAIL-R1 and TRAIL-R2 [12], infection does not down-regulate TRAIL receptors so TRAIL resistance is more likely due to alteration of intracellular signaling [13]. Tat up-regulation of Bcl-2 has been invoked as an anti-apoptotic mechanism in Kaposi's sarcoma cells [14], in primary human macrophages and PBMC [15], and in HeLa, CD4+ and monocytic cell lines $[16,17]$; herein we are extending those observations to primary human monocytes. The antiapoptotic effects of $\mathrm{Bcl}-2$ are believed to be primarily targeted at the mitochondrial membranes, although direct effects on caspases have also been reported. Bcl-2 thus represents a pivotal gene for regulating apoptosis, with both upstream and downstream effects. Its upregulation may prevent monocyte/macrophage apoptosis from a variety of apoptotic stimuli, including downstream stimuli that may be activated by viral infection $[18,19]$. A mechanism by which Tat upregulates Bcl-2 by signaling through VEGF receptor 2, activating phosphatidylinositol 3-kinase and causing CD40/Traf-3 engagement has been elucidated for Kaposi's sarcoma cells $[20]$ and may also be relevant for primary human monocytes.

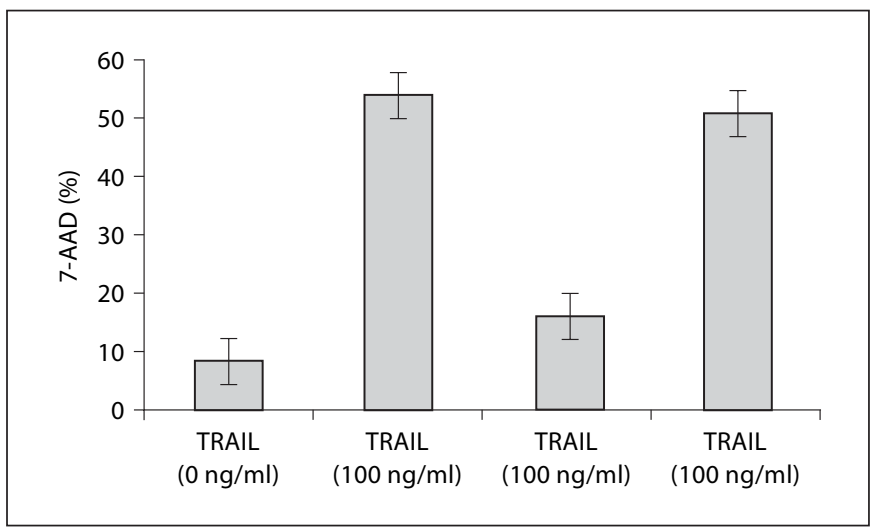

Fig. 4. HIV Tat protein protects monocytes from apoptosis induced by TRAIL (7-AAD staining). (1) Monocytes + media, (2) monocytes $+100 \mathrm{ng} / \mathrm{ml}$ rTRAIL, (3) Tat-treated monocytes +100 ng/ml rTRAIL, (4) (anti-TRAIL + anti-Tat)-treated monocytes $100 \mathrm{ng} / \mathrm{ml} \mathrm{rTRAIL}$ were incubated for $20 \mathrm{~h}$ and then stained with 7-AAD as described in 'Materials and Methods'. Bar represents the means \pm SEM from three independent experiments, each carried out in triplicate.

This study focused on HIV Tat protein because it plays a important role in the pathogenesis of HIV infection. Our results confirm that HIV Tat treated monocytes are relatively resistant to TRAIL-mediated cell death, a mechanism that might contribute to viral persistence or establishment of the latent reservoir.

\section{Acknowledgements}

The project was supported by the Scientific Research Foundation for Returned Overseas Chinese Scholars, State Education Ministry to Y.D.Y.

\section{References}

1 Gallo RC: Tat as one key to HIV-induced immune pathogenesis and Tat toxoid as an important component of a vaccine. Proc Natl Acad Sci USA 1999;96:8324-8326.

2 Sodroski J, Patarca R, Rosen C, Wong-Staal F, Haseltine W: Location of the transactivating region on the genome of human T-cell lymphotropic virus type III. Science 1985; 229:74-79.

- 3 Westendorp MO, Frank R, Ochsenbauer C, Stricker K, Dhein J, Walczak H, Debatin KM, Krammer PH: Sensitization of T cells to CD95-mediated apoptosis by HIV-Tat and gp120. Nature 1995;375:497-500.
-4 Albini A, Ferrini S, Benelli R, Sforzini S, Giunciuglio D, Aluigi MG: HIV Tat protein mimicry of chemokines. Proc Natl Acad Sci USA 1998;95:13153-13158.

5 Zagury D, Lachgar A, Chams V, Fall LS, Bernard J, Zaugury JF, Bizzini B, Gringeri A, Santagostino E, Capitani S: Interferon alpha and Tat involvement in the immunosupression of uninfected $\mathrm{T}$ cells and C-C chemokine decline in AIDS. Natl Acad Sci USA 1998;95:3851-3859.
6 Yang Y, Tikhonov I, Ruckwardt TJ, Djavani M, Zapata JC, Pauza CD, Salvato MS: Monocytes treated with human immunodeficiency virus Tat kill uninfected CD4+ cells by a tumor necrosis factor-related apoptosis-induced ligand-mediated mechanism. J Virol 2003;77:6700-6708.

7 Crowe SM: Role of macrophages in the pathogenesis of human immunodeficiency virus infection. Aust NZ J Med 1995;25:777783.

8 Rosenberg ZF, Fauci AS: Immunopathogenic mechanisms of HIV infection. Clin Immunol Immunopathol 1989;50:S149-S156. 
$\checkmark 9$ Badley AD, McElhinnyJA, Leibson PJ, Lynch $\mathrm{DH}$, Alderson MR, Paya CV: Upregulation of Fas ligand expression by human immunodeficiency virus in human macrophage mediates apoptosis of uninfected $\mathrm{T}$ lymphocytes. J Virol 1996;70:199-206.

$>10$ Lecoeur H, Ledru E, Prevost MC, Gougeon ML: Strategies for phenotyping apoptotic peripheral human lymphocytes comparing ISNT, annexin-V and 7-AAD cytoflurometric staining methods. J Immunol Methods 1997;209:111-123.

-11 Zhang M, Li X, Pang X, Ding L, Wood O, Clouse K, Hewlett I, Dayton AI: Identification of a potential HIV-induced source of bystander-mediated apoptosis in T cells: upregulation of TRAIL in primary human macrophages by HIV-1 Tat. J Biomed Sci 2001;8:290-296.
12 MacFarlane M, Harper N, Snowden RT, Dyer MJ, Barnett GA, Pringle JH, Cohen GM: Mechanisms of resistance to TRAIL-induced apoptosis in primary B cell chronic lymphatic leukaemia. Oncogene 2002;21: 6809-6818.

13 Lum JJ, Andre PA, Sanchez-Dardon J, Phenix BN, Kim JE, Mihowhich J, Janison K, Hawley-Foss N, Lynch DH, Badley AD: Induction of cell death in human immunodeficiency virus-infected macrophages and resting memory CD4 T cells by TRAIL/ Apo2l. J Virol 2001;75:11128-11136.

14 Cantaluppi V, Deregibus MC, Biancone L, Deambrosis I, Bussolati B, Albini A, Camussi G: The expression of CD154 by Kaposi's sarcoma cells mediates the anti-apoptotic and migratory effects of HIV-1-TAT protein. Int Immunopathol Pharmacol. 2006;19:81-96.

$\checkmark 15$ Zhang M, Li X, Pang X, Ding L, Wood O, Clouse K, Hewlett I, Dayton AL: Bcl-2 upregulation by HIV TAT during infection of primary human macrophages in culture. J Biomed Science 2002;9:133-139.
16 Zauli G, Gilbellini ZG: The human immunodeficiency virus type-1(HIV-1) Tat protein and Bcl-2 gene expression. Leuk Lymphoma 1996;23:551-560.

17 Zauli G, Gilbellini D, Caputo A, Bassini A, Negrini M, Monne M, Mazzoni M, Capitani S: The human immunodeficiency virus type1 Tat protein upregulates $\mathrm{Bcl}-2$ gene expression in Jurkat T-cell lines and primary peripheral blood mononuclear cells. Blood 1995;86:3823-3834.

18 Dales JP, Palmerini F, Devilard E, Hassoun J, Birg F, Xerri L. Caspases: Conductors of the cell death machinery in lymphoma cells. Leuk Lymphoma 2001;41:247-253.

19 Cross A, McDonnell, Korsmeyer SJ: Bcl-2 family members and the mitochondria in apoptosis. Genes Dev 1999;13:1899-1911.

20 Deregibus MC, Cantaluppi V, Doublier S, Brizzi MF, Deambrosis I, Albini A, Camussi G: HIV-1-Tat protein activates phosphatidylinositol 3-kinase/ AKT-dependent survival pathways in Kaposi's sarcoma cells. J Biol Chem 2002;277:25195-25202. 